\title{
In vitro antifungal efficacy of selected essential oils in controlling fungi associated with the stem-end rot disease of mango (cv. Karutha Colomban) fruits and characterisation of antifungal components
}

\author{
TD Kodituwakku ${ }^{1}$, GCM Ekanayake ${ }^{1}$, KP Abeywickrama ${ }^{1 *}$ and R Jayakody ${ }^{2}$ \\ ${ }^{\prime}$ Department of Plant and Molecular Biology, Faculty of Science, University of Kelaniya, Kelaniya. \\ ${ }^{2}$ Department of Botany, Faculty of Natural Sciences, The Open University of Sri Lanka, Nawala, Nugegoda.
}

Submitted: 26 March 2019; Revised: 05 August 2019; Accepted: 27 September 2019

\begin{abstract}
Karutha Colomban is one of the most delightful mango varieties popular among Sri Lankan consumers. A significant postharvest loss of mango takes place every season due to diseases including stem-end rot (SER), which is caused by a group of endophytic fungal pathogens. In this research, in vitro antifungal efficacy of different concentrations of essential oils of basil, clove, and cinnamon were evaluated for their ability to control SER causing fungal pathogens of mango (cv. Karutha Colomban) as bio-safe alternatives to conventional fungicides, by conducting liquid and disc volatilisation bioassays. Major bioactive compounds of the selected essential oils were identified by gas chromatography-mass spectroscopy (GC-MS). Basil and cinnamon bark oils $(0.20-0.30 \mu \mathrm{L} / \mathrm{mL})$ in liquid bioassay showed high efficacy against Lasiodiplodia theobromae, while basil and cinnamon leaf oils (0.40 $0.60 \mu \mathrm{L} / \mathrm{mL}$ ) successfully inhibited Pestalotiopsis sp. Cinnamon bark oil $(0.60 \mu \mathrm{L} / \mathrm{mL})$ was identified as the most effective oil against Phomopsis sp. According to disc volatilisation bioassay, vapour of cinnamon oils $(0.20-0.40 \mu \mathrm{L} / \mathrm{mL})$ was the most effective in controlling $L$. theobromae. Pestalotiopsis sp. was efficiently controlled by clove and cinnamon bark oil $(0.20-$ $0.60 \mu \mathrm{L} / \mathrm{mL}$ ) vapour. In vapour phase, clove and cinnamon oils $(0.40 \mu \mathrm{L} / \mathrm{mL})$ were the most effective against Phomopsis sp. According to GC-MS characterisation, methyl chavicol was the most abundant antifungal component in basil oil while it was (E)-cinnamaldehyde in cinnamon bark oil. Moreover, eugenol displayed the highest abundance in clove and cinnamon leaf oils. Based on in vitro studies, it could be concluded that cinnamon bark oil in liquid and vapour phases demonstrated a higher antifungal efficacy among the tested essential oils in controlling fungal pathogens causing SER of mango.
\end{abstract}

Keywords: Antifungal, essential oils, GC-MS, mango, stemend rot.

\section{INTRODUCTION}

Mango (Mangifera indica L.) is a popular fruit worldwide and it has become one of the most desirable fruits in international trade because of its delightful taste and high caloric value (Diedhiou et al., 2007). It bears important nutrients such as vitamins, minerals, polyphenolic and flavonoid antioxidant compounds as well as prebiotic dietary fiber (Kothalawala \& Jayasinghe, 2017). Asia is recognised as the highest mango producing region, with a record $74.4 \%$ of global production. Present extent under mango cultivation in Sri Lanka is about 3.1 million hectares (FAOSTAT, 2016). 'Karutha Colomban' is one of the most popular cultivars of mango among growers and consumers in Sri Lanka due to its orange flesh and delightful taste (Kothalawala \& Jayasinghe, 2017).

However, the availability of high quality mango for the local and international consumers has been limited by its highly perishable nature and susceptibility to postharvest diseases, which lead to severe postharvest lossess (Bally et al., 2009). Stem-end rot (SER) is considered as one of the most serious and frequently occurring postharvest and post-packaging diseases of mango (Tripathi \& Shukla, 2009). SER is caused by a complex of fungi

\footnotetext{
* Corresponding author (kris@kln.ac.lk; (10) https://orcid.org/0000-0001-6562-3151)
} 
namely, Lasiodiplodia theobromae (syn. Botryodiplodia theobromae), Neofusicoccum parvum (syn. Dothiorella dominicana), $N$. mangiferae (syn $D$. mangiferae), Phomopsis mangiferae, Pestalotiopsis mangiferae and Colletotrichum gloeosporioides (Abeywickrama, 2006; Jabeen, 2016; Ekanayake, 2017).

At present, the disease control strategies include prophylactic use of synthetic fungicides to treat fruit crops including mango. Although fungicide usage is a successful chemical control strategy for postharvest diseases of many fruits, it has given rise to many controversial issues owing to their carcinogenicity, acute toxicity, long degradation periods, environmental pollution and contribution to the development of resistant pathogens. Due to these environmentally unsound effects, researchers are focusing on finding effective alternatives to synthetic fungicides in controlling postharvest diseases of fruits (Tripathi \& Shukla, 2009).

Essential oils extracted from plants are generally assumed to be more acceptable and less hazardous than synthetic compounds as they possess bioactive properties, due to the presence of many chemical components such as eugenol, camphor, camphene, caryophyllene, phellandrene, etc. (Bakkali et al., 2008; Zaker, 2016). In several previous studies, it has been recorded that essential oils of cinnamon (Cinnamomum zeylanicum) leaf and bark, clove (Syzygium aromaticum), and basil (Ocimum basilicum) as very effective sources of antifungal compounds (Ranasinghe, 2003; Sukatta et al., 2008; Abeywickrama et al., 2009; Costa et al., 2015).

An in vitro liquid bioassay conducted by Anthony et al. (2004) showed that the essential oils of Cymbopogon nardus and $O$. basilicum have inhibited $L$. theobromae isolated from banana with crown rot disease at the minimum concentrations of 1.0 and $0.8 \mu \mathrm{L} / \mathrm{mL}$, respectively. According to Abeywickrama et al. (2003), vapour of basil oil at $0.05 \%-0.2 \%$ has found to be fungicidal against banana crown rot pathogens including L. theobromae. Dip treatment with cardamom (Elettaria cardamomum) oil at $0.70 \mu \mathrm{L} / \mathrm{mL}$ has significantly reduced SER of Karutha Colomban mango (Karunanayake et al., 2018). Furthermore, fumigation with the essential oil of Amomum subulatum leaf has successfully controlled SER of mango (cv. Dasheri) (Dubey et al., 2008).

The objectives of the present study were (i) to investigate in vitro bioactive efficacy of essential oils of cinnamon (i.e. leaf and bark), basil, and clove as eco-friendly antifungal agents against SER- associated fungi (L. theobromae, Pestalotiopsis sp., and Phomopsis sp.) isolated from Karutha Colomban mango, and (ii) to characterise these oils to identify effective antifungal components using gas chromatography-mass spectroscopy (GC-MS).

\section{METHODOLOGY}

\section{Essential oils}

Ocimum basilicum (basil) oil was purchased from Aromatica Laboratories (Pvt.) Ltd., Colombo 11. Cinnamomum zeylanicum (cinnamon) leaf oil, cinnamon bark oil and Syzygium aromaticum (clove) oil were purchased from Citro Essential Oils (Pvt.) Ltd., Mt. Lavinia. Extra pure eugenol as an authentic standard was obtained from Loba Chemie Indoaustranal Co., India. Carbendazim fungicide as a positive control was purchased from Hayleys Agriculture Holdings Ltd., Colombo 10.

\section{Test fungi}

SER-associated fungi, isolated and characterised in a previous study (Ekanayake, 2017) through morphology and molecular tools and designated as Lasiodiplodia theobromae (MH005085.1), Pestalotiopsis sp. (MH005090.1) and Phomopsis sp. (MH005086.1), were used for this study.

\section{In vitro bioassays to determine the antifungal effects of essential oils}

\section{Liquid bioassay}

According to the method described by Anthony et al. (2004), conical flasks $(100 \mathrm{~mL})$ containing $50 \mathrm{~mL}$ of SMKY semi synthetic liquid medium ( $7.0 \mathrm{~g}$ yeast extract, $1.5 \mathrm{~g} \mathrm{KNO}_{3}, 20.0 \mathrm{~g}$ sucrose and $0.50 \mathrm{~g} \mathrm{MgSO}_{4} .7 \mathrm{H}_{2} \mathrm{O}$ dissolved in $1 \mathrm{~L}$ of distilled water) was autoclaved for 20 min at $1.03 \mathrm{~kg} \mathrm{~cm}^{-2}$ and $121^{\circ} \mathrm{C}$. A concentration series of oils; $0.10-1.00 \mu \mathrm{L} / \mathrm{mL}$ was prepared aseptically adding appropriate volumes of test oils to the flasks, and Tween 80 (Koch-Light Laboratories, England) was used as a surfactant to disperse oil. Each assay flask was then separately inoculated with a $5 \mathrm{~mm}$ diameter fungal disc cut from the periphery of a 7-day old pure culture of the respective test pathogen. Contents were mixed thoroughly by placing the flasks on reciprocal water bath shaker (New Brunswick Scientific, Model: R76) at room temperature $\left(28 \pm 2{ }^{\circ} \mathrm{C}\right)$. A control (sterilised 
distilled water and Tween 80 without oil) was included for comparison. Eugenol $(2.00 \mu \mathrm{L} / \mathrm{mL})$ prepared in a similar manner was used as an authentic standard to observe the antifungal efficacy. Carbendazim fungicide $(0.1 \% \mathrm{w} / \mathrm{v})$ was used as the positive control. Six replicates of each treatment and controls were arranged according to completely randomised design (CRD) in the laboratory. After $7 \mathrm{~d}$ of incubation, the mycelia (if any) were recovered on pre-weighed filter paper (Whatman No: 1, $5.5 \mathrm{~cm}$ diameter), washed three times with sterile distilled water, and placed in a hot air oven (Memmert, UM 600) at $105^{\circ} \mathrm{C}$ overnight until a constant weight was reached to determine the mycelial dry weight (Anthony et al., 2004). The inhibition percentage was determined using the following equation.

$$
\text { Inhibition } \%=[(\mathrm{C}-\mathrm{T}) / \mathrm{C}] \times 100
$$

$\mathrm{C}=$ mean dry weight of mycelium in control flasks $\mathrm{T}=$ mean dry weight of mycelium in test flasks

\section{Disc volatilisation bioassay}

Petri plates $(90 \times 15 \mathrm{~mm})$ containing potato dextrose agar (PDA) medium (15 mL per plate) were inoculated with a $5 \mathrm{~mm}$ diameter mycelial plug from the periphery of a 7-day old pure culture of the respective test pathogen (Perumal et al., 2016). A sterilised filter paper disc with a diameter of $90 \mathrm{~mm}$ (Whatman No: 1) was placed on the inner surface of the Petri dish lid. Aliquots of the essential oil ranging from $2.0-20.0 \mu \mathrm{L}$ were added onto the filter paper discs placed in separate Petri dishes. A filter paper soaked with sterile distilled water served as the control. Similar treatments with eugenol $(20.0 \mu \mathrm{L})$ and ethanol $(100.0 \mu \mathrm{L})$ were used as authentic standard and positive control, respectively. The Petri plates were sealed with para-film immediately after adding essential oil, placed in an inverted position and incubated at room temperature for $7 \mathrm{~d}$ (Feng et al., 2011). The experimental design was a CRD with 6 replicates per treatment and controls. The radial mycelial growth of each test pathogen was evaluated after $7 \mathrm{~d}$ of incubation by measuring the colony diameter along two axes at right angles to each other. These values were compared with those of untreated controls. The antifungal efficacy was expressed as the percentage inhibition of radial mycelial growth (\% IRMG) using the following formula (Abdollahi et al., 2011).

$$
\% \mathrm{IRMG}=[(\mathrm{dc}-\mathrm{dt}) / \mathrm{dc}] \times 100
$$

$\mathrm{dc}=$ mean radial mycelial growth in control Petri plates $\mathrm{dt}=$ mean radial mycelial growth in treatment Petri plates

\section{Determination of minimum inhibitory and minimum lethal values of test oils}

The mycelial plugs that did not show any growth in each in vitro bioassay were transferred to freshly prepared PDA plates and incubated for $7 \mathrm{~d}$ at room temperature $\left(28 \pm 2^{\circ} \mathrm{C}\right)$ to observe the recovery of the mycelial growth, in order to differentiate between the fungicidal and fungistatic activity of the selected essential oil treatments. Any revival of radial mycelial growth was categorised as the fungistatic effect and the corresponding concentration of the test oil was considered as the minimum inhibitory concentration (MIC). No growth of fungal mycelia (no revival) was considered as fungicidal effect and the corresponding concentration of the test oil was considered as minimum lethal concentration (MLC) (Sellamuthu et al., 2013; Bill et al., 2015; Perumal et al., 2016).

\section{Gas chromatography-mass spectroscopy analysis of test oils}

Basil, clove, cinnamon leaf, and bark oils were subjected to GC-MS analysis at the Industrial Technology Institute, Malabe. The analysis was carried out using a GC apparatus (Thermoscientific Trace 1300 model) equipped with an auto-injector AI 1310 (Thermoscientific) and a fused silica capillary column (Rtx-wax) of $30 \mathrm{~m} \times$ $0.25 \mathrm{~mm}$ i.d., $0.25 \mu \mathrm{m}$ film (Thermoscientific), using helium as the carrier gas with a flow rate of $1.0 \mathrm{~mL}$ $\mathrm{min}^{-1}$. The temperature was programmed to start at 60 ${ }^{\circ} \mathrm{C}$, followed by an increase at a rate of $5{ }^{\circ} \mathrm{C} \mathrm{min}{ }^{-1}$ until $220{ }^{\circ} \mathrm{C}$ was reached, then maintaining at $220{ }^{\circ} \mathrm{C}$ for 10 $\mathrm{min}$. The temperatures of the injector and the ion source were $240{ }^{\circ} \mathrm{C}$ and $250{ }^{\circ} \mathrm{C}$, respectively. A volume of 0.3 $\mu \mathrm{L}$ essential oil diluted with $1 \mathrm{~mL}$ of hexane was injected at a partitioning rate of injected volume of 1:50 and a column pressure of $64.20 \mathrm{kPa}$. The MS was carried out with an ion capture detector operating in electronic impact mode with impact energy of $70 \mathrm{eV}$, a scan interval of 0.50 fragments, and fragments detected in the range of $50-450 \mathrm{Da}$. The essential oil components were identified by comparing the mass spectrum with spectra from the equipment database (NIST11). Additionally, the retention rates were compared with those in the literature (Adams, 2007).

\section{Data analysis}

Data with respect to in vitro bioassays were analysed using two-way analysis of variance (ANOVA), using Minitab 17 statistical software. The mean separation was done using Tukey's multiple comparison test (Anthony et al., 2004). 


\section{RESULTS AND DISCUSSION}

\section{Antifungal efficacy of essential oils in liquid phase}

In vitro liquid bioassay technique allows determination of the antifungal activity of essential oils which are in direct contact with the mycelia of fungal pathogens growing in an aqueous medium (Anthony et al., 2004). Out of the tested oils, basil oil was the most effective against $L$. theobromae which displayed $100 \%$ mycelial inhibition at $0.20 \mu \mathrm{L} / \mathrm{mL}$. Cinnamon bark oil was equally effective and achieved complete inhibition of mycelia of L. theobromae at $0.25 \mu \mathrm{L} / \mathrm{mL}$. Clove and cinnamon leaf oils were slightly less effective against $L$. theobromae and displayed $100 \%$ mycelial inhibition only at $0.40 \mu \mathrm{L} / \mathrm{mL}$ (Figure 1). Accordingly, each of these concentrations were considered as MIC values for basil, cinnamon bark, clove and cinnamon leaf oils, respectively (Table 1). With respect to the fungicidal effect, basil oil was more effective against $L$. theobromae than other oils, with an MLC of $0.20 \mu \mathrm{L} / \mathrm{mL}$. According to two-way ANOVA, percentage inhibition values obtained for different oils were significantly different from the control when the test oil type, concentration and the interaction between test oil type $\times$ concentration were considered $(p<0.05)$. According to a similar liquid bioassay carried out by Anthony et al. (2004), basil oil was fungistatic as well as fungicidal at a minimum concentration of $0.80 \mu \mathrm{L} / \mathrm{mL}$ against $L$. theobromae isolated from banana, which is comparatively greater than MIC and MLC values determined by the present study. MLC values of cinnamon bark and clove oils against $L$. theobromae were slightly higher being 0.30 and $1.00 \mu \mathrm{L} / \mathrm{mL}$, respectively (Table 1). According to a previous record (Ranasinghe et al., 2002) on a liquid bioassay using the same liquid medium, cinnamon bark oil was found to be fungicidal against $L$. theobromae isolated from banana at $0.45 \mu \mathrm{L} / \mathrm{mL}$, which is slightly greater than the present value. MLC of clove oil against $L$. theobromae determined by Ranasinghe et al. (2002) was $0.60 \mu \mathrm{L} / \mathrm{mL}$. However, present MLC value of clove oil against the same pathogen was somewhat lower compared to the previous result. The present MLC of cinnamon leaf oil against $L$. theobromae was $1.00 \mu \mathrm{L} / \mathrm{mL}$ and it is slightly greater than the value reported by Ranasinghe et al. (2002) (i.e. $0.80 \mu \mathrm{L} / \mathrm{mL}$ ).

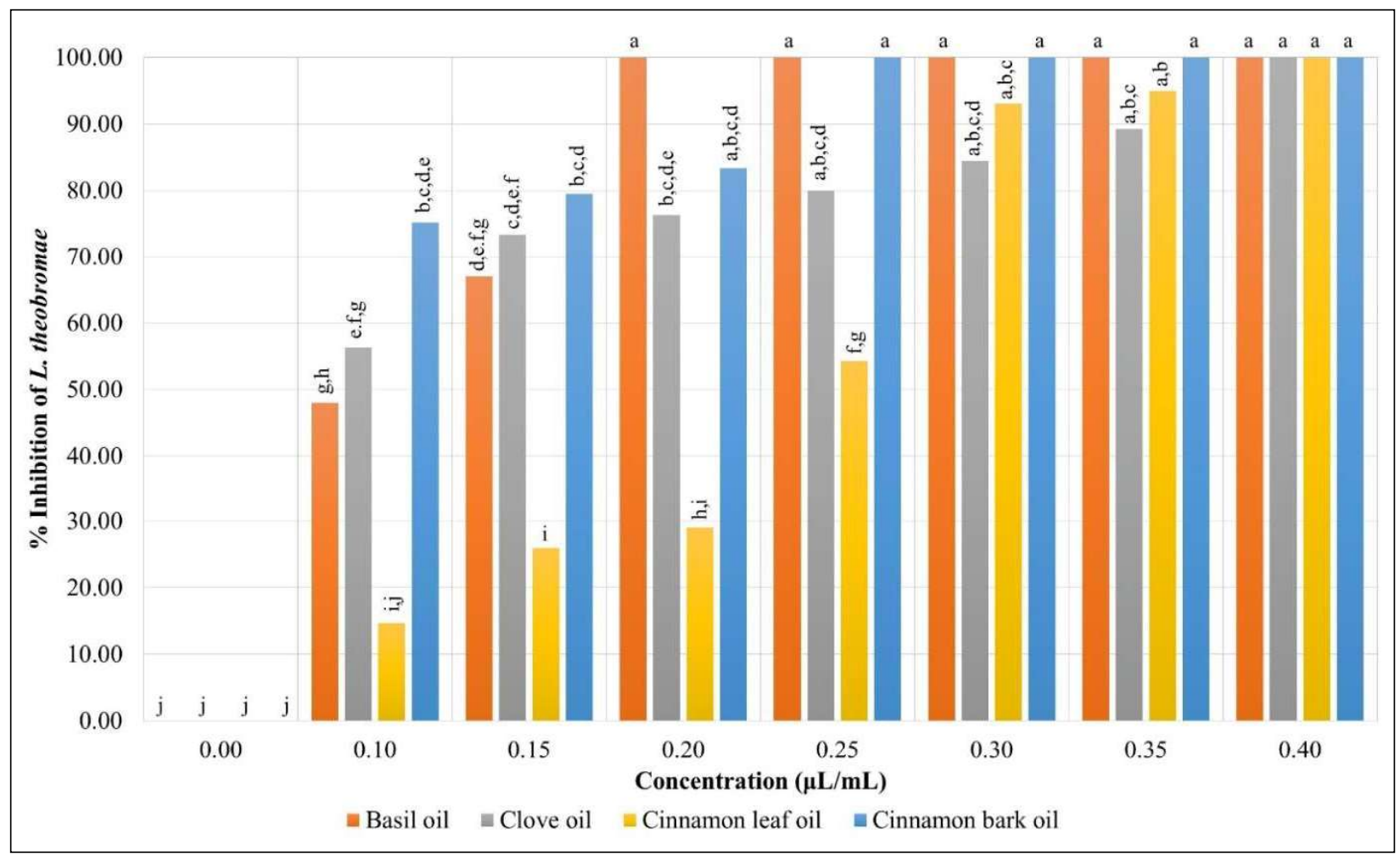

Figure 1: Inhibitory effect of test oils on the growth of L. theobromae in liquid bioassay. Each data point represents the mean of six replicates Means sharing a common letter(s) are not significantly different by Tukey's multiple comparison test at $\mathrm{p}<0.05$. 
Table 1: Minimum inhibitory and minimum lethal concentrations (MICs and MLCs) of test oils against SER-associated fungi of mango as determined by the liquid bioassay.

\begin{tabular}{|c|c|c|c|c|c|c|}
\hline \multirow[t]{2}{*}{ Test oil } & \multicolumn{2}{|c|}{ L. theobromae } & \multicolumn{2}{|c|}{ Pestalotiopsis sp. } & \multicolumn{2}{|c|}{ Phomopsis sp. } \\
\hline & $\begin{array}{c}\mathrm{MIC}^{\mathrm{a}} \\
(\mu \mathrm{L} / \mathrm{mL})\end{array}$ & $\begin{array}{l}\mathrm{MLC}^{\mathrm{b}} \\
(\mu \mathrm{L} / \mathrm{mL})\end{array}$ & $\begin{array}{c}\mathrm{MIC}^{\mathrm{a}} \\
(\mu \mathrm{L} / \mathrm{mL})\end{array}$ & $\begin{array}{l}\mathrm{MLC}^{\mathrm{b}} \\
(\mu \mathrm{L} / \mathrm{mL})\end{array}$ & $\begin{array}{c}\mathrm{MIC}^{\mathrm{a}} \\
(\mu \mathrm{L} / \mathrm{mL})\end{array}$ & $\begin{array}{l}\mathrm{MLC}^{\mathrm{b}} \\
(\mu \mathrm{L} / \mathrm{mL})\end{array}$ \\
\hline Basil & 0.20 & 0.20 & 0.60 & 0.60 & 0.80 & 0.80 \\
\hline Clove & 0.40 & 1.00 & 0.60 & 1.00 & 0.60 & 0.80 \\
\hline Cinnamon leaf & 0.40 & 1.00 & 0.40 & 0.60 & 0.60 & 0.80 \\
\hline Cinnamon bark & 0.25 & 0.30 & 0.40 & 0.80 & 0.60 & 0.60 \\
\hline
\end{tabular}

Growth of Pestalotiopsis sp. was completely inhibited by most of the test oils at very low concentrations (i.e. $0.40-0.60 \mu \mathrm{L} / \mathrm{mL}$; Figure 2). Cinnamon leaf and bark oils were effective against Pestalotiopsis sp., as they displayed $100 \%$ growth inhibition (MIC) at a lower concentration (i.e. $0.40 \mu \mathrm{L} / \mathrm{mL}$; Figure 3 ) and fungicidal effect (MLC) between $0.60-0.80 \mu \mathrm{L} / \mathrm{mL}$ (Table 1). Basil and clove oils exhibited fungistatic effect against Pestalotiopsis sp. at a slightly higher concentration (i.e. $0.60 \mu \mathrm{L} / \mathrm{mL}$ ). Further, MLC of basil oil was also recorded

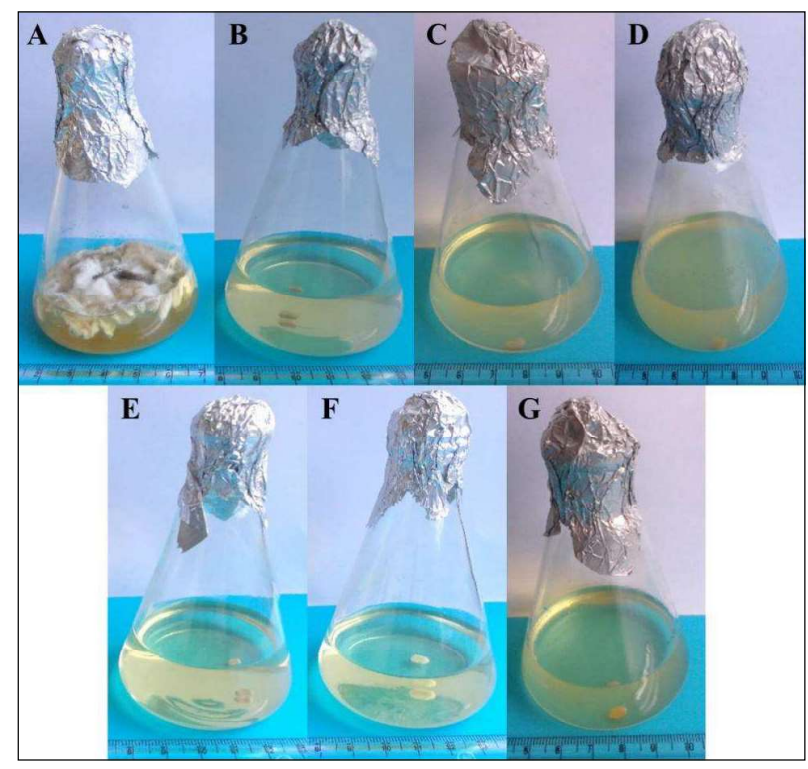

Figure 2: Antifungal effect of test oils, eugenol and carbendazim against Pestalotiopsis sp. in liquid bioassay after 7 days of incubation at $28 \pm 2{ }^{\circ} \mathrm{C}$ [Negative control (A); $0.60 \mu \mathrm{L} / \mathrm{mL}$ basil oil (B); $0.60 \mu \mathrm{L} / \mathrm{mL}$ clove oil (C); $0.40 \mu \mathrm{L} / \mathrm{mL}$ cinnamon leaf oil (D); $0.40 \mu \mathrm{L} / \mathrm{mL}$ cinnamon bark oil (E); $2.00 \mu \mathrm{L} / \mathrm{mL}$ eugenol $(\mathrm{F})$; and $0.1 \%(\mathrm{w} / \mathrm{v})$ carbendazim $(\mathrm{G})]$. at $0.60 \mu \mathrm{L} / \mathrm{mL}$ indicating its fungicidal effect. The twoway ANOVA revealed that, results obtained for test oils were significantly different from the control when the test oil type, concentration and the interaction between test oil type $\times$ concentration were considered as factors $(\mathrm{p}<0.05)$.

Further, clove, cinnamon leaf and cinnamon bark oils were more effective than basil oil in terms of fungistatic activity against Phomopsis sp. (Table 1; Figure 3). MIC of basil oil was $0.80 \mu \mathrm{L} / \mathrm{mL}$, which was slightly greater than the MICs of clove and two cinnamon oils (i.e. $0.60 \mu \mathrm{L} / \mathrm{mL}$ ). However, when considering the fungicidal activity, cinnamon bark oil was the most effective against Phomopsis sp. than other oils. Percentage inhibition values were significantly different when concentration and interaction of test oil type $x$ concentration were considered as factors $(\mathrm{p}<0.05)$. However, there was no significant difference in percentage inhibition when only test oil type was considered as a factor $(p>0.05)$. Carbendazim and eugenol at fixed concentrations $(0.1 \% \mathrm{w} / \mathrm{v}$ and $2.00 \mu \mathrm{L} / \mathrm{mL}$, respectively) completely inhibited the growth of all test fungi revealing high antifungal efficacy (data not presented). Eugenol is a bioactive compound found in the essential oils of many higher plants and its antifungal action has been confirmed by many studies (Herath \& Abeywickrama, 2008; Wang et al., 2010).

\section{Antifungal activity of essential oils in vapour phase}

In vitro disc volatilisation bioassay was carried out to identify the vapour phase effect of each essential oil against the growth of test fungi on a solid medium. The volatile nature of the bioactive compounds present in essential oils allows them to act against many fungal pathogens (Bill et al., 2015). Vapour of clove, cinnamon 


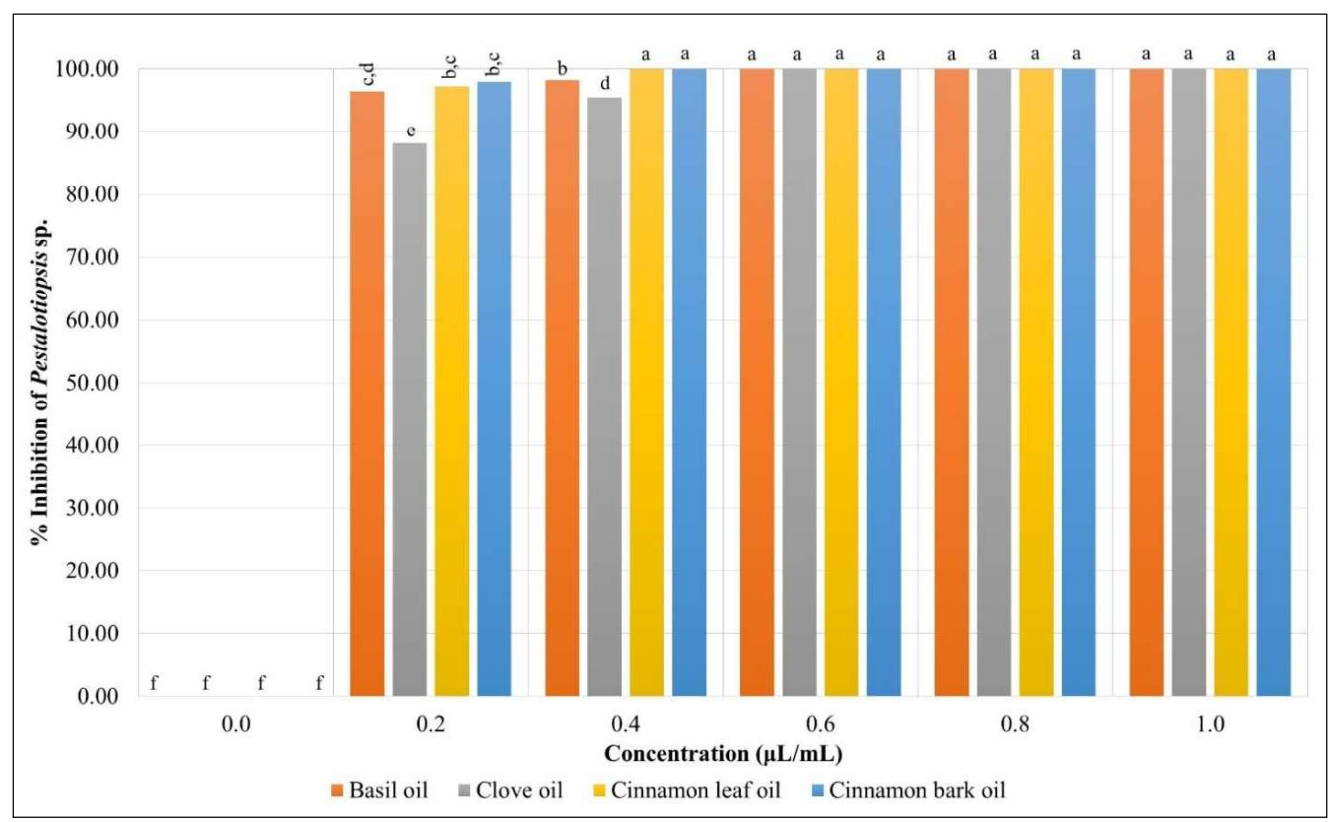

Figure 3: Inhibitory effect of test oils on the growth of Pestalotiopsis sp. in liquid bioassay. Each data point represents the mean of six replicates. Means sharing a common letter(s) are not significantly different by Tukey's multiple comparison test at $\mathrm{p}<0.05$.

Table 2: Minimum inhibitory and minimum lethal concentrations (MICs and MLCs) of test oils against SERassociated fungi of mango as determined by the disc volatilisation bioassay.

\begin{tabular}{|c|c|c|c|c|c|c|}
\hline \multirow[t]{2}{*}{ Test oil } & \multicolumn{2}{|c|}{ L. theobromae } & \multicolumn{2}{|c|}{ Pestalotiopsis sp. } & \multicolumn{2}{|c|}{ Phomopsis sp. } \\
\hline & $\begin{array}{c}\text { MIC }^{\mathrm{a}} \\
(\mu \mathrm{L} / \text { plate })\end{array}$ & $\begin{array}{c}\text { MLC }^{\text {b }} \\
(\mu \mathrm{L} / \text { plate })\end{array}$ & $\begin{array}{c}\text { MIC }^{\mathrm{a}} \\
(\mu \mathrm{L} / \text { plate })\end{array}$ & $\begin{array}{c}\text { MLC }^{b} \\
(\mu \mathrm{L} / \text { plate })\end{array}$ & $\begin{array}{c}\text { MIC a } \\
(\mu \mathrm{L} / \text { plate })\end{array}$ & $\begin{array}{c}\text { MLC }^{\mathrm{b}} \\
(\mu \mathrm{L} / \text { plate })\end{array}$ \\
\hline Basil & 10.0 & Not achieved & 16.0 & 16.0 & 12.0 & 12.0 \\
\hline Clove & 2.0 & Not achieved & 2.0 & 6.0 & 4.0 & 4.0 \\
\hline Cinnamon leaf & 2.0 & 4.0 & 4.0 & 8.0 & 4.0 & 4.0 \\
\hline Cinnamon bark & 2.0 & 2.0 & 2.0 & 4.0 & 4.0 & 4.0 \\
\hline
\end{tabular}

a Zero radial mycelial growth at minimum inhibitory concentration; ${ }^{\mathrm{b}}$ Zero revival of fungus at minimum lethal concentration.

leaf, and cinnamon bark oils showed a complete inhibition of radial mycelial growth at $2.0 \mu \mathrm{L} /$ plate concentration against $L$. theobromae (Table 2). However, according to Sukatta et al. (2008), higher concentration of cinnamon bark oil (i.e. $10 \mu \mathrm{L} /$ plate) was needed for $100 \%$ inhibition of mycelial growth of $L$. theobromae, while clove oil at the same concentration controlled the growth of $L$. theobromae only up to $74.07 \%$. Further, in the present study, cinnamon leaf and cinnamon bark oils showed a fungicidal effect against $L$. theobromae at concentrations of $2.0 \mu \mathrm{L} /$ plate and $4.0 \mu \mathrm{L} /$ plate respectively, whereas, clove oil failed to inhibit the pathogen growth completely. Basil oil vapour achieved a $100 \%$ IRMG at a concentration of $10.0 \mu \mathrm{L} /$ plate and was the least effective oil against $L$. theobromae compared to other test oils, which could not display fungicidal effect either (Table 2). Abeywickrama et al. (2003) reported that basil oil showed a high antifungal effect against banana fruit pathogens, Colletotrichum musae, Fusarium proliferatum and L. theobromae at very low concentrations (i.e. $\mathrm{MLC}=0.05-0.20 \%$ ) comparable with the results of the present research. 
According to Table 2, clove and cinnamon bark oils achieved a $100 \%$ IRMG of Pestalotiopsis sp. at a MIC of $2.0 \mu \mathrm{L} /$ plate. Therefore, effectiveness of those two oils in the vapour form was high, when compared to basil and cinnamon leaf oils, having fungistatic effects at 16.0 and $4.0 \mu \mathrm{L} /$ plate concentrations, respectively. Fungicidal activity of clove and cinnamon bark oils (i.e. $\mathrm{MLC}=6.0$ and $4.0 \mu \mathrm{L} /$ plate, respectively) was more pronounced against Pestalotiopsis sp. than that of basil and cinnamon leaf oils (i.e. $\mathrm{MLC}=16.0$ and $8.0 \mu \mathrm{L} /$ plate, respectively). Since clove oil demonstrated relatively lower MIC and MLC values than basil oil, it could be considered as a moderately effective fumigant against Pestalotiopsis sp. Clove, cinnamon leaf, and cinnamon bark oils displayed fungistatic as well as fungicidal effects against Phomopsis sp. at a concentration of $4.0 \mu \mathrm{L} /$ plate. This value was notably less than the MIC and MLC of basil oil (i.e. $12.0 \mu \mathrm{L} /$ plate) against Phomopsis sp. Therefore, efficacy of basil oil vapour against Phomopsis sp. was relatively less than that of clove and cinnamon oils, which could be recognised as the best oils in controlling the target pathogen (Table 2). According to Sukatta et al. (2008), a different strain of Phomopsis (P. viticola) was completely inhibited by cinnamon bark oil at $10 \mu \mathrm{L} /$ plate concentration, while clove oil at the same concentration controlled the growth of $P$. viticola up to $91 \%$. However, the present MIC and MLC values of clove and cinnamon bark oils against mango SER-associated Phomopsis sp. were notably lower when compared to the results of the former study. According to the present study eugenol $(20 \mu \mathrm{L} /$ plate $)$ at vapour phase was capable of inhibiting all test pathogens, completely. Although ethanol $(100 \mu \mathrm{L} /$ plate) was used as the positive control in this fumigation assay, it was unable to inhibit the growth of test fungi, completely. However, \% IRMG values for ethanol were 21.60 and $50.62 \%$ for Pestalotiopsis sp. and Phomopsis sp., respectively. According to Bacílková (2006), vapour of ethanol at $30-90 \%(\mathrm{v} / \mathrm{v})$ has totally controlled Aspergillus niger and Penicillium notatum, which are commonly considered as saprophytes. Since absolute ethanol was used against the two pathogenic fungi tested in the present study, a complete inhibition could not be achieved.

\section{GC-MS characterisation of test oils}

GC-MS analysis of the selected essential oils revealed the major chemical constituents of each tested essential oil along with their relative abundance. In basil oil, methyl chavicol was the major compound with a relative abundance of $74.44 \%$ with relatively low amounts of eugenol and (E)-cinnamaldehyde (Table 3). However, eugenol was the most abundant constituent in both clove and cinnamon leaf oils. (E)-cinnamaldehyde in cinnamon leaf was relatively low. The composition of cinnamon bark oil consisted of $72.18 \%$ (E)-cinnamaldehyde with a low abundance of eugenol. Linalool, which is one of the antifungal constituents present in many essential oils, was detected in basil, cinnamon leaf, and cinnamon bark oils with percentages of 15.01, 1.27 and 3.69, respectively (Table 3 ). All these chemical constituents have previously been reported as bioactive antifungal compounds against many postharvest pathogenic fungi. Methyl chavicol, which is the most abundant component present in basil oil was found to be antifungal against two postharvest pathogenic fungi viz, C. gloeosporioides and Alternaria alternata (Costa et al., 2015). Eugenol, which was recognised as one of the most effective bioactive components present in the test oils has previously been reported for its strong antifungal activity against C. musae, F. proliferatum, and Botrytis cinerea (Herath \& Abeywickrama, 2008; Wang et al., 2010). According to Hong et al. (2015) and Marei and Abdelgalei (2018), cinnamaldehyde was found to be antifungal against C. gloeosporioides, B. cinerea, Aspergillus niger, and Penicillium digitatum. Further, Soković and van Griensven (2006) have identified linalool as an antifungal agent of controlling Verticillium fungicola and Trichoderma harzianum. Although several antifungal components are present in a single oil in different proportions, they appear to act synergistically to inhibit the growth of target fungi (Anthony et al., 2004).

Antimicrobial constituents of essential oils affect cell structure by causing disruption of cell membrane, alteration of cell membrane integrity, and inhibition of cell wall formation. Integrity and functionality of cell membranes are governed by ergosterols, a structural component of cell membranes. Bioactive compounds of essential oils can bind with ergosterols or act as specific inhibitors that inhibit the biosynthesis of ergosterols, causing cell membrane destruction. Essential oils can also inhibit the cell wall formation by blocking the formation of $\beta$-glucans in fungi, which is one of the important constituents of the cell wall (Nazzaro et al., 2017). Damage to cell wall and cell membrane by essential oils can cause leakage of macromolecules and electrolytes and cell lysis of pathogens (Bakkali et al., 2008). Leakage of contents of $C$. musae and $F$. proliferatum conidia treated with essential oils of Ocimum basilicum, Cymbopogon citratus, eugenol and citral was reported by Herath and Abeywickrama (2008). Essential oils are also known to cause the dysfunction of mitochondria and inhibition of efflux pumps causing serious damages to pathogens. Mitochondrial electron transport chain can be inhibited by the antimicrobial constituents of essential oils, which reduce the mitochondrial membrane potential of fungal pathogens. Activity of proton pumping ATPases can be 
Table 3: Chemical components of tested essential oils, their retention time (RT) and relative abundance (RA) as determined by GC-MS

\begin{tabular}{|c|c|c|c|c|c|c|c|c|}
\hline \multirow[t]{2}{*}{ Compound } & \multicolumn{2}{|c|}{ Basil oil } & \multicolumn{2}{|c|}{ Clove oil } & \multicolumn{2}{|c|}{ Cinnamon leaf oil } & \multicolumn{2}{|c|}{ Cinnamon bark oil } \\
\hline & $\begin{array}{l}\mathrm{RT} \\
(\mathrm{min})\end{array}$ & $\begin{array}{l}\text { RA } \\
(\%)\end{array}$ & $\begin{array}{l}\mathrm{RT} \\
(\mathrm{min})\end{array}$ & $\begin{array}{l}\text { RA } \\
(\%)\end{array}$ & $\begin{array}{l}\mathrm{RT} \\
(\mathrm{min})\end{array}$ & $\begin{array}{l}\text { RA } \\
(\%)\end{array}$ & $\begin{array}{l}\mathrm{RT} \\
(\mathrm{min})\end{array}$ & $\begin{array}{l}\text { RA } \\
(\%)\end{array}$ \\
\hline Anethole & 18.21 & 0.27 & - & - & - & - & - & - \\
\hline Benzaldehyde & 23.89 & 0.35 & - & - & - & - & 12.69 & 0.06 \\
\hline Benzyl benzoate & - & - & - & - & 34.23 & 3.61 & 34.25 & 1.51 \\
\hline$\delta$-Cadinene & - & - & 17.69 & 0.30 & - & - & - & - \\
\hline Calamenene & - & - & 19.37 & 0.14 & - & - & - & - \\
\hline Camphene & - & - & - & - & 3.63 & 0.25 & 3.66 & 0.04 \\
\hline$\alpha$-Caryophyllene & - & - & 15.79 & 1.04 & 15.79 & 0.39 & - & - \\
\hline$\beta$-Caryophyllene & - & - & 14.15 & 9.07 & 14.15 & 2.48 & 14.17 & 3.95 \\
\hline Caryophyllene oxide & - & - & 22.53 & 0.40 & 22.53 & 0.30 & 22.55 & 0.30 \\
\hline Cinnamaldehyde, (E)- & 24.19 & 1.63 & - & - & 23.82 & 1.37 & 23.85 & 72.18 \\
\hline Cinnamaldehyde, $(Z)-$ & - & - & - & - & - & - & 20.88 & 0.16 \\
\hline Cinnamyl acetate & - & - & - & - & 25.83 & 1.08 & 25.47 & 5.16 \\
\hline Copaene & - & - & 11.69 & 0.34 & 11.69 & 0.42 & 11.71 & 0.21 \\
\hline$\rho$-Cymene & - & - & - & - & 6.89 & 0.82 & 6.91 & 0.35 \\
\hline D-Limonene & - & - & 5.53 & 0.03 & 5.52 & 0.25 & 5.54 & 0.09 \\
\hline Epoxylinalool & 11.65 & 1.57 & - & - & - & - & - & - \\
\hline Eugenol & 26.41 & 0.71 & 26.15 & 79.11 & 26.14 & 63.76 & 26.17 & 4.82 \\
\hline Eugenol acetate & - & - & 27.76 & 0.20 & 27.76 & 2.27 & - & - \\
\hline Geranyl vinyl ether & 17.71 & 0.19 & - & - & - & - & - & - \\
\hline Humulene & - & - & - & - & - & - & 15.81 & 0.45 \\
\hline Iso- $\beta$-terpineol & 6.07 & 0.13 & - & - & - & - & - & - \\
\hline Linalool & 13.35 & 15.01 & - & - & 13.03 & 1.27 & 13.05 & 3.69 \\
\hline Methyl chavicol & 16.23 & 74.44 & - & - & - & - & - & - \\
\hline $\begin{array}{l}\text { 1-methyl-4-(1-methylethyl)- } \\
\text { cyclohexanol }\end{array}$ & 15.51 & 0.24 & - & - & - & - & - & - \\
\hline Methyl salicylate & - & - & 18.32 & 0.11 & - & - & - & - \\
\hline 1,2-Oxolinalool & 10.99 & 1.60 & - & - & - & - & - & - \\
\hline$\alpha$-Phellandrene & - & - & - & - & 4.96 & 0.68 & 4.98 & 0.12 \\
\hline$\beta$-Phellandrene & - & - & 5.72 & 0.02 & 5.71 & 0.40 & 5.73 & 0.32 \\
\hline$\alpha$-Pinene & 3.52 & 0.02 & 3.17 & 0.09 & 3.16 & 0.91 & 3.18 & 0.17 \\
\hline$\beta$-Pinene & - & - & - & - & 4.14 & 0.21 & 4.16 & 0.04 \\
\hline Safrole & - & - & - & - & 20.35 & 0.96 & 20.37 & 0.11 \\
\hline Terpinen-4-ol & - & - & - & - & 14.35 & 0.07 & - & - \\
\hline$\alpha$-Terpinene & & & 5.21 & 0.07 & 5.20 & 0.12 & 5.22 & 0.04 \\
\hline$\gamma$-Terpinene & - & - & 6.38 & 0.08 & - & - & - & - \\
\hline$\alpha$-Terpineol & 16.83 & 0.10 & - & - & 16.49 & 0.15 & 16.51 & 0.06 \\
\hline Trans-4-methoxycinnamaldehyde & 33.40 & 1.28 & - & - & - & - & - & - \\
\hline Trans- $\alpha$-bergamotene & 14.23 & 0.43 & - & - & - & - & - & - \\
\hline
\end{tabular}

inhibited by the essential oils, which diminishes ATP production in microorganisms. Inhibition of efflux pumps by essential oil constituents will disturb the removal of toxic substances out of the cell (Nazzaro et al., 2017). Essential oils are also capable of damaging cytoplasmic lipids and proteins leading to coagulation of cytoplasm (Bakkali et al., 2008). Many other mechanisms of action for various oil components have been proposed and tested against several fungal pathogens. As essential oils tested in this study contain many bioactive components in different proportions, it could be assumed that they act synergistically in inhibiting the mango SER pathogens with the aid of one or more mechanisms of action as highlighted in the literature. 


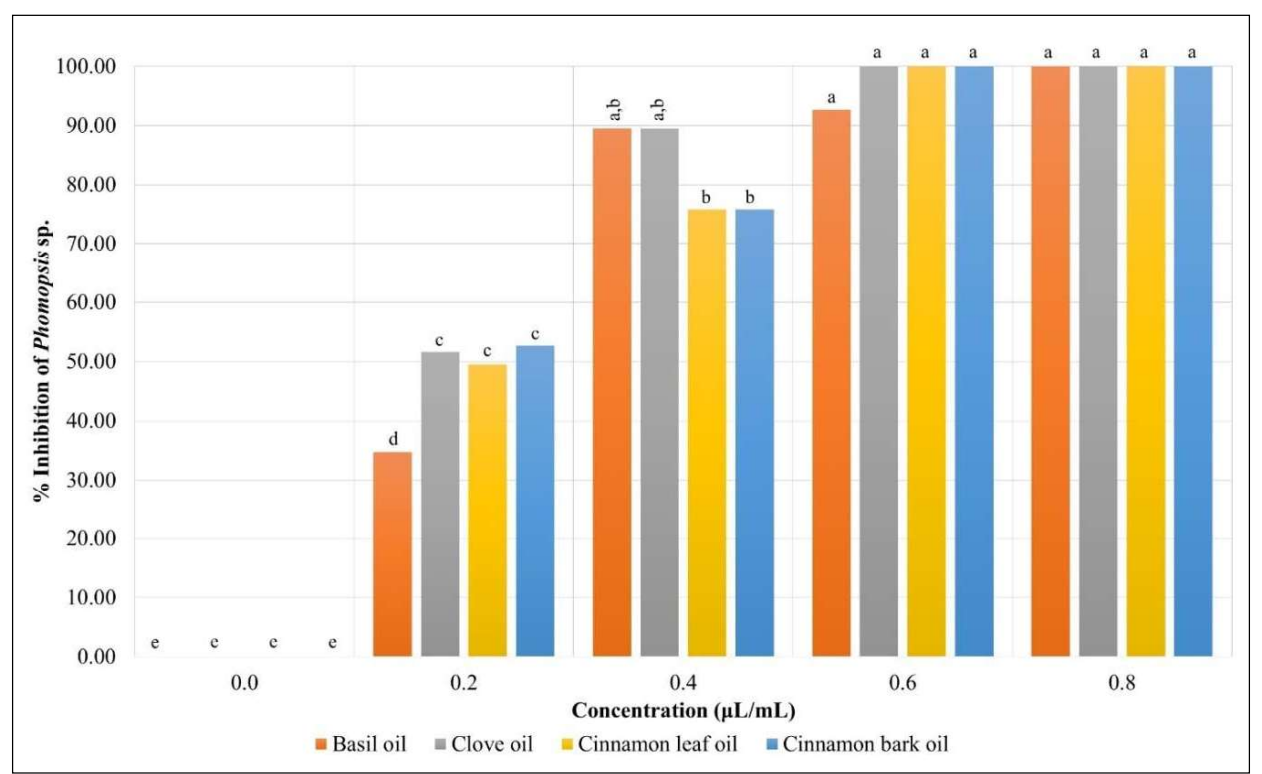

Figure 4: Inhibitory effect of test oils on the growth of Phomopsis sp. in liquid bioassay. Each data point represents the mean of six replicates. Means sharing a common letter(s) are not significantly different by Tukey's multiple comparison test at $\mathrm{p}<0.05$.

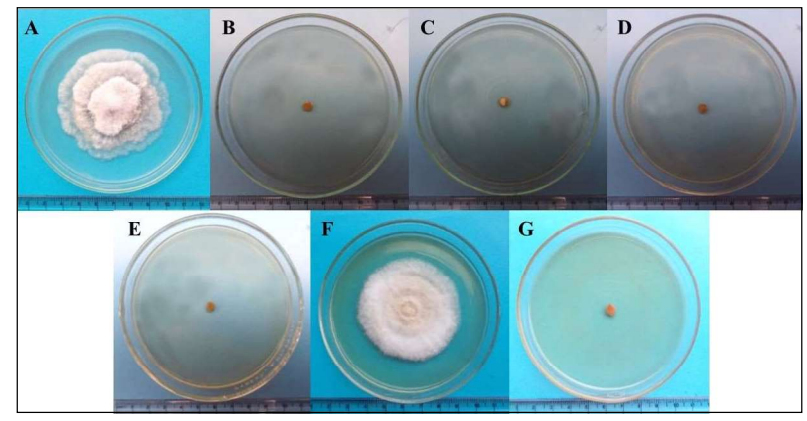

Figure 5: Antifungal effect of test oils, eugenol and carbendazim against Pestalotiopsis sp. in disc volatilisation bioassay after 7 days of incubation at $28 \pm 2{ }^{\circ} \mathrm{C}$ [Negative control (A); $16.0 \mu \mathrm{L} /$ plate basil oil (B); $2.0 \mu \mathrm{L} /$ plate clove oil (C); $4.0 \mu \mathrm{L} /$ plate cinnamon leaf oil (D); $2.0 \mu \mathrm{L} /$ plate cinnamon bark oil (E); $100 \mu \mathrm{L} /$ plate ethanol (F); and $20 \mu \mathrm{L} /$ plate eugenol (G)]

\section{CONCLUSION}

According to the in vitro bioassays carried out during the present study, liquid and vapour forms of basil, clove, and cinnamon oils successfully controlled SER-associated fungi of mango, viz. L. theobromae, Pestalotiopsis sp., and Phomopsis sp. However, their effectiveness depends on the type of oil and the fungal species tested. In general, cinnamon bark oil at liquid and vapour phases displayed a higher in vitro antifungal efficacy against the above SER associated fungi isolated from Karutha Colomban mango. The results highlight the importance of formulating suitable spray or fumigation treatments using these essential oils as eco-friendly alternatives to conventional fungicides, to control SER of mango in order to lengthen the postharvest storage life. Since, L. theobromae was the main pathogen frequently isolated from mango with SER, novel essential oil treatments could be focused towards controlling $L$. theobromae along with other SER-associated pathogens. Liquid spray and fumigation treatment systems are being currently developed in vivo to control SER in Karutha Colomban mango in combination with passive modified atmosphere packaging and cold storage.

\section{Acknowledgement}

This research was funded by University of Kelaniya, Sri Lanka (Research Grant: RP/03/02/01/02/2017)

\section{REFERENCES}

Abdollahi A.L.I., Hassani A., Ghosta Y., Meshkatalsadat M.H. \& Shabani R. (2011). Screening of antifungal properties of essential oils extracted from sweet basil, fennel, summer 
savory and thyme against postharvest phytopathogenic fungi. Journal of Food Safety 31(3): 350-356. DOI: https://doi.org/10.1111/j.1745-4565.2011.00306.x

Abeywickrama K. (2006). A Pictorial Guide to Rapid and Accurate Identification of Postharvest Diseases of Fruits, $1^{\text {st }}$ edition, pp. 17-56. Godage International Publishers, Colombo, Sri Lanka.

Abeywickrama K., Anthony S. \& Watawala R. (2003). Fumigant action of selected essential oils against banana fruit pathogens. Journal of the National Science Foundation of Sri Lanka 31(3-4): 427-429.

DOI: http://doi.org/10.4038/jnsfsr.v31i3-4.2469

Abeywickrama K., Wijerathna C., Herath H. \& Sarananda K.H. (2009). An integrated treatment of basil oil (Ocimum basilicum) and alum with modified atmosphere to control crown rot disease in Embul banana. Tropical Agricultural Research and Extension 12(1): 23-30.

DOI: https://doi.org/10.4038/tare.v12i1.1980

Adams R.P. (2007). Identification of essential oil components by gas chromatography/mass spectroscopy, $4^{\text {th }}$ edition, pp. 31-51. Allured Publishing Corporation, Illinois, USA.

Anthony S., Abeywickrama K., Dayananda R., Wijeratnam S.W. \& Arambewela L. (2004). Fungal pathogens associated with banana fruit in Sri Lanka, and their treatment with essential oils. Mycopathologia 157: 91-97.

DOI: https://doi.org/10.1023/B:MYCO.0000012226.95628.99

Bacílková B. (2006). Study on the effect of butanol vapours and other alcohols on fungi. Restaurator 27: 186-199. DOI: https://doi.org/10.1515/REST.2006.186

Bakkali F., Averbeck S., Averbeck D. \& Idaomar M. (2008). Biological effects of essential oils - A review. Food and Chemical Toxicology 46(2): 446-475.

DOI: https://doi.org/10.1016/j.fct.2007.09.106

Bally I.S., Lu P. \& Johnson P.R. (2009). Mango Breeding. In: Breeding Plantation Tree Crops: Tropical Species (eds. S.M. Jain \& P.M. Priyadarshan), pp. 51-82. Springer Science and Business Media Inc., New York, USA. DOI: https://doi.org/10.1007/978-0-387-71201-7_2

Bill M., Sivakumar D., van Rooyan Z. \& Mavuso Z.S.S. (2015). New methods of postharvest disease control: using thyme oil fumigation. South African Avocado Growers' Association Yearbook 38: 98-104.

Costa L.C.B., Pinto J.E.B.P., Bertolucci S.K.V., Costa J.C.D.B., Alves P.B. \& Niculau E.D.S. (2015). In vitro antifungal activity of Ocimum selloi essential oil and methylchavicol against phytopathogenic fungi. Revista Ciência Agronômica 46(2): 428-435.

DOI: http://dx.doi.org/10.5935/1806-6690.20150023

Diedhiou P.M., Mbaye N., Dramé A. \& Samb P.I. (2007). Alteration of postharvest diseases of mango Mangifera indica through production practices and climatic factors. African Journal of Biotechnology 6(9): 1087-1094.

Dubey R.K., Kumar R., Chansouria J.P.N. \& Dubey N.K. (2008). Evaluation of Amomum subulatum roxb oil as a source of botanical fungitoxicant for the protection of mango fruits from fungal rotting. Journal of Food Safety 28(3): 400-412.

DOI: https://doi.org/10.1111/j.1745-4565.2008.00108.x
Ekanayake E.M.G.C.M. (2017). In vitro antifungal effect of selected essential oils on stem-end rot disease of mango (Mangifera indica L.). BSc thesis, University of Kelaniya, Kelaniya.

FAOSTAT (2016). FAO Statistics, Food and Agriculture Organization of the United Nations, Rome, Italy. Available at http://www.fao.org/faostat/en/\#home, Accessed 9 April 2018.

Feng W., Chen J., Zheng X. \& Liu Q. (2011). Thyme oil to control Alternaria alternata in vitro and in vivo as fumigant and contact treatments. Food Control 22(1): 78-81. DOI: https://doi.org/10.1016/j.foodcont.2010.05.010

Herath H. \& Abeywickrama K. (2008). In vitro application of selected essential oils and their major components in controlling fungal pathogens of crown rot in Embul banana (Musa acuminate-AAB). International Journal of Food Science and Technology 43(3): 440-447.

DOI: https://doi.org/10.1111/j.1365-2621.2006.01465.x

Hong J.K., Yang H.J., Jung H., Yoon D.J., Sang M.K. \& Jeun Y.C. (2015). Application of volatile antifungal plant essential oils for controlling pepper fruit anthracnose by Colletotrichum gloeosporioides. The Plant Pathology Journal 31(3): 269-277.

DOI: https://doi.org/10.5423/PPJ.OA.03.2015.0027

Jabeen A. (2016). Field and postharvest biology of dendritic spot and stem end rot of mango. $P h D$ thesis, The University of Queensland, Brisbane, Australia.

Karunanayake C., Kulasinghe A., Somaratne S. \& Adikaram N. (2018). Control of stem-end rot disease in mango fruit cultivar 'Karuthacolomban' using non-agrochemical methods. In: Plant health in a global economy. Proceedings of International Congress of Plant Pathology (ICPP) 2018, The American Phytopathological Society (APS), USA, pp. 855-P. Available at https://apsnet.confex.com/apsnet/ ICPP2018/meetingapp.cgi/Paper/8788, Accessed 1 May 2019.

Kothalawala S.G. \& Jayasinghe J.M.J.K. (2017). Nutritional evaluation of different mango varieties available in Sri Lanka. International Journal of Advanced Engineering Research and Science 4(7): 128-131.

DOI: https://dx.doi.org/10.22161/ijaers.4.7.20

Marei G.I.K. \& Abdelgaleil S.A.M. (2018). Antifungal potential and biochemical effects of monoterpenes and phenylpropenes on plant pathogenic fungi. Plant Protection Science 54(1): 9-16. DOI: https://doi.org/10.17221/9/2017-PPS

Nazzaro F., Fratianni F., Coppola R. \& De Feo V. (2017). Essential oils and antifungal activity. Pharmaceuticals 10(4): 86 . DOI: https://doi.org/doi:10.3390/ph10040086

Perumal A.B., Sellamuthu P.S., Nambiar R.B. \& Sadiku E.R. (2016). Antifungal activity of five different essential oils in vapour phase for the control of Colletotrichum gloeosporioides and Lasiodiplodia theobromae in vitro and on mango. International Journal of Food Science and Technology 51(2): 411-418.

DOI: https://doi.org/10.1111/ijfs. 12991

Ranasinghe L., Jayawardena B. \& Abeywickrama K. (2002). 
Fungicidal activity of essential oils of Cinnamomum zeylanicum (L.) and Syzygium aromaticum (L.) Merr et L.M. Perry against crown rot and anthracnose pathogens isolated from banana. Letters in Applied Microbiology 35(3): 208-211.

DOI: https://doi.org/10.1046/j.1472-765X.2002.01165.x

Ranasinghe L.S. (2003). Investigation of biochemical and pathological changes following postharvest treatment of Musa acuminata (var.Embul) with essential oils. MPhil thesis, University of Kelaniya, Kelaniya.

Sellamuthu P.S., Sivakumar D. \& Soundy P. (2013). Antifungal activity and chemical composition of thyme, peppermint and citronella oils in vapour phase against avocado and peach postharvest pathogens. Journal of Food Safety 33(1) 86-93.

DOI: https://doi.org/10.1111/jfs.12026

Soković M. \& van Griensven L.J.L.D. (2006). Antimicrobial activity of essential oils and their components against the three major pathogens of the cultivated button mushroom, Agaricus bisporus. European Journal of Plant Pathology
116(3): 211-224.

DOI: https://doi.org/10.1007/s10658-006-9053-0

Sukatta U., Haruthaithanasan V., Chantarapanont W., Dilokkunanant U. \& Suppakul P. (2008). Antifungal activity of clove and cinnamon oil and their synergistic against postharvest decay fungi of grape in vitro. Kasetsart Journal (Natural Science) 42: 169-174.

Tripathi P. \& Shukla A.K. (2009). Application of essential oils for postharvest control of stem end rot of mango fruits during storage. International Journal of Postharvest Technology and Innovation 1(4): 405-415. DOI: https://doi.org/10.1504/IJPTI.2009.030689

Wang C., Jie Z., Hao C., Yongjian F. \& Zhiqi S. (2010). Antifungal activity of eugenol against Botrytis cinerea. Tropical Plant Pathology 35(3): 137-143. DOI: http://dx.doi.org/10.1590/S1982-56762010000300001

Zaker M. (2016). Natural plant products as eco-friendly fungicides for plant diseases control - A review. The Agriculturists 14(1): 134-141.

DOI: https://doi.org/10.3329/agric.v14i1.29111 